821.163.41.08-32 Андрић И.

811.163.41'373.23

https://doi.org/10.18485/sj.2018.23.1.46

АНКА Ж. СИМИТ

Универзитет у Крагујевцу

Филолошко-уметнички факултет

АНА С. ЖИВКОВИЋ ${ }^{* *}$

Универзитет у Крагујевацу

Филолошко-уметнички факултет
Оригинални научни рад

Примљен: 04. 01. 2018.

Прихваћен: 29. 01. 2018.

\title{
ЈЕЗИК ЉУБАВИ У ПРИПОВЕТКАМА БОРЕ СТАНКОВИЋА: ВЛАСТИТА ИМЕНА И УЗВИЦИ***
}

\begin{abstract}
Примењујући сазнања из области антропонимије (науке о именима људи), опште лингвистике и филозофске херменеутике, у раду истражујемо вишеструка значења властитих имена и узвика̂ у трима приповеткама Боре Станковића: „У виноградима”, „У ноћи” и „Покојниковој жени”. Управљамо пажњу на семантичке разлике међу узвицима 'ax', 'ех' и 'ох' предочавајући не само степене трагичности Станковићевих јунака већ и својеобразну граматику љубави, вербалну и трансвербалну посебност пишчевог језика. На основу нашег истраживања, закључујемо да Станковићева поетика љубави не настаје само употребом једноврсних лингвистичких средстава, усмерених ка јасним и конкретним референтима, већ отвара могућности и за далекосежније семантичке нијансе српског језика, за хипотетичка означавања лексичким и граматичким структурама, за појединачне и јединствене вредности.

Кључне речи: Борисав Станковић, властите именице, узвици, предвербално, трансвербално

*ankaristic@yahoo.com

**ja.zanita@yahoo.com

**** Овај рад је део истраживања која се изводе на пројекту 178018 Друштвене кризе $u$ савремена српска киижевност и култура: национални, регионални, европски и глобални оквир и пројекту 178025 Поетика српског реализма, које финансира Министарство просвете, науке и технолошког развоја Републике Србије.
\end{abstract}




\section{УВОД}

Властита имена имају конкретнија, обухватнија значења него што се то обично препознаје, јер је „за једну одређену заједницу, значење једног властитог имена збир обавештења којима располаже о носиоцу тог имена, с тим да је сваком члану заједнице познат бар један број тих обавештења" (Дикро, Тодоров 1987: 147). Уочавајући да су, у погледу опсега онога о чему она саопштавају, имена у књижевним делима нарочито репрезентативна, у овом раду опсервирамо неке облике именовања и експресивног говора остварених између заљубљених бића у приповеткама „У ноћи”, „У виноградима” и „Покојникова жена" Борисава Станковића. Фигура вољеног бића подразумева јединственост и незамењивост, пред њом се - што је очито у моментима ћутања и муцања - редуцира говор онда када се љубав снажно доживљава или када се у том доживљају открива нешто што ту љубав онемогућава. Верујући да се семантичка неисцрпност појма љубави може најпотпуније изразити личним именом, Епштејн напомиње: „Свако лично име, као и личне заменице 'ја' или 'ти', без обзира на широку употребу, носи у себи оповргавање своје заједничке употребе. Значење личног имена у целини одређује она индивидуа на коју се оно односи у чину говора" (Епштејн 2012: 302). Станковићеви јунаци улазе у нову реалност узајамног разумевања, вољења, патње или чежње, управо посредством једва изговорених имена или једва чујних узвика. У језик љубави уписан је „субјект који не влада дискурсом него дискурс њиме, чија трагедија остаје заувек (не)исписана писмом које мора да тежи хаотичности, некохерентности, тишини, прећутаном, пошто оно друго што се јавља у субјекту, онај други дискурс, насхватљив је, фрагментаран, у константном превазилажењу ефеката реалног и контроле" (Бошковић 2017: 63). Како би се разумела вредност властитих имена из стилистичког аспекта, неопходно је узети у разматрање и могућност изражавања индивидуализованих садржаја, односно идиоматичност или произвољност (немотивисаност) знаковне структуре. Казујући о стилској апликацији знаковних јединица, Радоје Симић напомиње важност процеса који се одвијају унутар језичког система:

„(а) У систему су језички знаци међусобно повезани мотивацијским везама; (б) те везе чине их функционално несамосталним, и стилски неутралним; (в) демотивација значи антиципацију знака, тј. кидање веза помоћу којега је уклопљен у систем; и значи - даље - његову индивидуализацију; (г) индивидуализовани знак има статус идиома, знаковног агрегата са стилски активном вредношћу” (Симић 2001: 286).

На основу реченог, властита/љубавна имена могу се тумачити као делимично самостални гласовни комплекси. Премда систем ограничава слободу ових знаковних ентитета, стилско активирање увек изнова ствара услове за превазилажење системске мотивације.

Поред властитих именица, узвици сигнализирају погранично подручје вербалног и трансвербалног, говора и тишине, обележавају да је оно што, са 
открићем љубави, у доживљају субјекта трепери пренесено и у сам језик, који се заталасава, помера, вибрира. Станковић не дозвољава јунацима да у потпуности занеме, да одустану од говора, већ их задржава на ивици, до које говор још увек постоји, али „не додавањем већ одузимањем речи” (Епштејн 2012: 274). Узбуђење повишеног степена препознајемо тамо где не преостаје ништа друго осим „узвичног” уздаха, који је истовремено глас дивљења пред вољеним и траг силаска са ума. На основу ситуација у којима се знатан део дијалога остварује тек узвичним екскламацијама, чини се да у Станковићевом тексту речи психофизиолошки делују на саговорника. Узвици се неретко јављају наместо властитих имена, функционишу као тајанствена замена тих имена, откривајући и мистификујући чин љубавног призивања. Наиме, пошто не може само именом изразити усхићење бића, писац открива регистар узвика, како би изговорио сложено догађање љубави. У теорији су већ уочени „заједнички напори језикотворства и лингвистике да ослобађају, узвикују и опевају љубавну енергију језика, скривену у његовој лексици и граматици" (Епштејн 2012: 302). Из лингвистичког аспекта, на основу досадашњих истраживања ${ }^{1}$, узвици се одређују као непотпуно формирани језички знаци, који „немају до краја издиференцираних дистинктивних обележја - ни на плану ознаке ни на плану означеног садржаја - већ још увек у великој мери чувају предлингвистичке одлике природних сигнала; упућују на телесна и духовна стања којима су изазвани по принципу узрочности” (Симић, Јовановић 2002а: 54-55).

\footnotetext{
${ }^{1}$ Проучавајући однос лингвиста према узвицима, Алма Чаркић казује: „Лингвистичка истраживања узвика у радовима лингвиста XX и XXI вијека, углавном се фокусирају на неуобичајеном гласовном саставу узвика, на њиховом гласовном симболизму, они се посматрају као остаци прелингвистичког кода, универзални природни знаци који се не морају учити" (Чаркић 2010: 400). Скрећући пажњу на то да поједини истраживачи узвике не одређују као засебну врсту речи, Алма Чаркић закључује: „Е. О. Ружички узвике сматра лексемама које су, са једне стране, непосредна, у великој мјери природна, а понекад чак несвјесна реакција на стварност, па у извјесном смислу имају право да изађу из фонолошких оквира датог језика, али са друге стране, не може им се негирати ни одређена конвенционалност. Српски лингвиста, А. Белић, иако узвике не сматра правим ријечима, разликује традиционалне узвике, од природних гласова који се јављају самоникло, изненада и спонтано, те представљају чисто рефлексивне звуке" (Чаркић 2010: 404-405). У свом раду „Граматичари о узвицима” Чаркићева подсећа: „Грчки граматичари узвике су сврставали у подврсту прилога, док су латински граматичари узвике убрајали у посебну врсту ријечи, гдје си ух сматрали синтаксички независним и тврдили да они изражавају емоције и стање свијести” (Чаркић 2009: 280). И додаје: „Словеначки граматичар J. Топоришич узвике или интерјекције сматра посебном непромјенљивом врстом ријечи. Овај граматичар дијели узвике у три категорије: први изражавају човјеково расположење (oh, eh, ih, uh, ah), други су ономатопејски и трећи императивни" (Чаркић 2009: 284). Када је посреди став српских граматичара, ауторка напомиње: „Српски граматичар Михаило Стевановић сматра да се узвицима не означава никакав одређени појам, већ неко неодређено осјећање. Тако да су то скупови гласова или поједини гласови којима се у афекту изражавају лична осјећања и расположења" (Чаркић 2009: 287).
} 
Када се у разговорима књижевних јунака редукују средства стварања референцијалне илузије, степен поетичности језика расте, што потврђује и Роман Јакобсон казујући о функционалности узвикаิ у језику: „Чисто емотивни слој језика представљају узвици. Они се од средстава референцијалног језика разликују како својим гласовним склопом (необичне гласовне секвенце, па чак и гласови који би другде били чудни) тако и својом синтаксичком улогом (они нису саставни делови реченица већ њихови еквиваленти)" (Јакобсон 1966: 290). Језик љубави непрекидно тежи сузбијању и укидању везе између знакова и предмета, што се остварује комуникативним прекидима, мумлањем, ућуткивањем. Стога све што јунакиња приповетке „У виноградима” може промуцати у тренутку могућег пољупца јесте једно: „м - м - м...” (Станковић 1970: $128)$, које јунак не може растумачити. Означавајући и пристанак на пољубац и забрану, мумлање се испоставља као вербални неспоразум међу јунацима, који изазива емотивну напетост у свету приче и семантичку двосмисленост приповетке, што показује да сви језички чиниоци стварају смисао једног дела, „све компоненте учествују у семантичком процесу који смо назвали контекстом" (Мукаржовски 1987: 211).

\section{ДРУШТВЕНА УСЛОВЉЕНОСТ ЉУБАВНОГ ГОВОРА}

Ленку, Цвету и Аницу - сагледавамо овим редоследом, који очитује скалу трагичности у одабраним Станковићевим приповеткама. Приказујући динамику културе и отварајући хоризонт психолошког живота јунака, Борисав Станковић предочава примере човека који пати и трпи, јер је, иако пун животне снаге, одвећ строго одрећен патријархалним васпитањем и друштвеним односима. Преко субјективних доживљаја својих јунака, Станковић приказује најскривеније домене (под)свести човека и оспољава страхове, стрепње и чежње, немогућност да се постигне живљење према жељи која из човека проговара. У овој разлици између жеље и могућности, између друштва и бића важно је идентификовати оно што је иза језичког стандарда културе - могућност трансвербалног - а онда и начине на које се то иза језика, као место на коме се биће субјекта разоткрива, у тексту Станковићевих приповедака ипак језички посредује. Дијалози између јунакиња и вољених мушкараца не само да откривају богатство Станковићевих поступака карактеризације женских ликова већ и незанемарљиве естетске вредности предвербалних феномена. Како би изразио драму егзистенције, приповедач проговара елиптичним реченицама, избегавајући нефункционалну реторику и банална значења. Драматичност живота, интензивно осећање судбинске важности неке промене, Станковић преноси у језик, па доживљени говор, у коме се приближавају перспективе јунака и приповедача, убедљиво репрезентује напор, патњу, грчеве, процепе, трауму. Снажне чулне доживљаје својих јунакиња Станковић приказује пре- 
ко момената њихове обнажености и страсне присности (услед усамљености чешће са собом, а ређе са другим бићем), тако што врхунце тих доживљаја концетрише у једној речи, у једном узвику или крику. Свака јунакиња има своју причу или песму, свака осећа чаму и непремостиви бол, у свакој постоји парадоксална чежња баш за оним што највише боли, чежња за властитом болешћу као за испуњењем судбине. Како би исказао специфичне перспективе, осећања, чежње и болове жена, Станковић употребљава одговарајућа језичка средства, међу којима су узвици посебно истакнути.

Подсећајући на Скерлићеве примедбе у вези са Станковићевом несигурном и невештом синтаксом, Новица Петковић је, поводом романа Нечиста крв, показао да су граматичка одступања одређена тачком гледишта унутар приповеданог призора: „Ту је, пре свега, тачка гледишта са које се призор у целини описује, и која је ауторова; она може бити, као што код Станковића често бива, преломљена у доживљају неког лика; затим долази тачка гледишта лика, или више ликова, што понекад води у врло сложене односе" (Петковић 1988: 54). У Нечистој крви приметни су бројни примери неправог управног говора, насталог укрштањем управног и неуправног говора, када аутор „само привидно говори у своје име, а уистину мање или више посредује говор ликова, којима се иначе сразмерно ретко даје да самостално узму реч” (Петковић 1988: 69). Своје испитивање језика у Станковићевом роману Петковић је концентрисао и око феномена реченичне и глаголске модалности, коју схвата на начин на који ју је одредио Александар Белић - као „однос према моментима који се налазе у самој говорној ситуацији, а који су сами по себи изван реченице: то је тренутак говора и став према односу субјекта и предиката онога ко говори" (Белић 1941, према: Петковић 1988: 69). Став јунака̂, њихова расположења и осећања у приповедном тексту Борисава Станковића преносе „модалне речи у реченици, модалне партикуле, затим речи са јачим конотативним набојем, па најзад, и нарочито, узвици” (Петковић 1988: 70). Петковићево скретање пажње на важност узвика у Станковићевој прози такође је у вези са Белићевим одређењем ове врсте речи: „То су гласови или комплекси гласова за још недовољно рашчлањена душевна стања у којима се налазе они који их употребљавају” (Белић 1959, према: Петковић 1988: 70).

Као фигуре заточених живота, паралисаних воља и великих чежњи, Станковићеве јунакиње проговарају - што је нарочито видно онда када говоре (о) вољеним мушкарцима - кроз кратке исказе, експресивне, аграматичне речи, које често нису семантизоване, премда су емоционално напрегнуте. Тако узбуђење продире у дискурс, а реченица постаје одраз стања самог субјекта. Немогућа реч „проговара” и једино она успева да посведочи о трагичном удесу идеализованих а немогућих љубави, о удесу субјеката који осећају тежину своје улоге у култури и који, вођени жељом својих бића, морају да из те културе некако изађу - у сновима, у лудилу, у смрти. И сам феномен естетског се 
у књижевности с краја 19. и почетка 20. века препознаје као вредност којом се индивидуално биће опире друштвеним и историјским условима. Напетост у односу између индивидуалног и друштвеног једна је од предметних и структуралних особености прозе српске модерне, а Александар Јерков ју je, на пример, очитао и као структурални принцип обликовања романа Иве Андрића: „Сазнање како је однос индивидуалног и друштвеног - преломљен у визури различитих живота и различитих времена - носилац романескне обликотворности значи више од тога: уместо да буде само једна од важних тема романа, ова структурална особеност је протумачена као уметничка основа обликовања" (Јерков 1992: 217-218).

Друштвена условљеност постојања одређује не само судбине Станковићевих подвојених субјеката већ и структуре приповедака заснованих на вербалним и трансвербалним феноменима. У приповедној грађи препознајемо представе одговарајућег начина живота, језика и мишљења (посредованих дијалекатским говором и песмама), као и представе обележене личним доживљајима, у којима су одражене и сучељене норме старе културе и осећања субјеката о својој срећи, али и о свом опадању и губитку унутар културе. Предметно и просторно средиште Станковићевих прозних дела чини свет Врања, са колективним и индивидуалним историјама, неспоразумима, неразумевањима, траумама и промашеностима. Простор о којем Станковић приповеда поседује специфичну поетску ауру: Врање је књижевна фигура у којој се преплићу љубав, лепота, младост, неслобода, нестанак, смрт. Станковића интересују морал заједнице и психологија субјекта, однос емоционалног и нагонског, присуство тамног, дубоког и расцепљеног у човеку, одређеност традицијом и строгим обичајним одредбама:

\footnotetext{
„Када сам га упознао, импресионирала ме је тврдокорност његове личности, тврдоћа и опорост његове физиономије. У њој су биле црте онога што носе људи који су годинама провели живот у тешким напорима, у печалби, у суровој борби за живот. Као да је та физиономија била избраздана ожиљцима живота" (Глигорић 1952: 6).
}

У свом књижевном делу Борисав Станковић је осветлио амбијент у коме се одиграва драма индивидуалних суноврата, али не само услед немогућности одупирања традицији, нормама старе и затворене културе, већ и услед открића да је модерни свет простор измењених и умањених могућности самог бића. У том свету биће не може да задобије оно што жели, јер криза и нестанак трансценденције, као темељно својство епохе, означавају недосежност љубави, среће и мира, неприступачност живота о коме се сања. То да биће нешто не може да добије, да досегне, да нечему не може да приступи Станковић је показао и у језику. 


\section{ПРЕДВЕРБАЛНО И ТРАНСВЕРБАЛНО}

У приповеци „У виноградима” пластично су приказани и берба грожђа, и врева коња̂, вика коњараิ, дечија цика, тискање женаิ у гомилама, улепљеност земљом и грожђаним соком. Приповедач у таквој атмосфери понавља Ленкино име, издвајајући јунакињу у један засебан свет, јер „биле су све наше: тетке, стрине, ујне, неке из комшилука; а била је и она, Ленка" (Станковић 1970: 122). Чини се, мимо света у виноградима, постоји још један фикционални свет онтолошки утемељен једино Ленкиним бићем, у коме се радња управља према њој, ,,једино ради ње, Ленке” (Станковић 1970: 123). Премда у дијалозима приповедач, који је истовремено и књижевни јунак, ниједном неће ословити именом јунакињу, Ленкино име учестало се јавља у наративним деоницама као сигнал непопустљивости љубавног осећања, као ритмичка истрајност заклетве. Властито име 'Ленка' с хипокористичним призвуком упућује на драго, умиљато, малено биће, уз које би приповедач да се приљуби и привије. Ленка се смањује и увећава, удаљава и приближава, постаје покретна и свуда присутна личност у приповедном свету, што и самог јунака изненађује: „Хтедох да прођем, кад - она, Ленка! Заобишла и стала ту. Чека ме" (Станковић 1970: 127). С обзиром на то да наведени пример изражава афективни садржај, представља заправо екскламативну реченицу, која постаје граматичко-стилистичка доминанта Станковићевог језика љубави. Потискујући референцијалност и информативност, те задобијајући експресивна значења, овакве реченице чине „средства експресивне синтаксе” (Бабић 2015: 55).

Међутим, када се љубавна чежња актуелизује, када се речи претворе у додир и загрљај, Ленка улази у нестабилни простор омеђен стидом и жељом за љубављу. С једне стране, недовољност љубави и потреба да се оголи сопствена празнина, испољавају се Ленкиним неиздрживим сладострасним узвикивањем: „Ох, мајчице моја!” (Станковић 1970: 125), док, с друге стране, страх и срамота због показане жеље, дрхтавица и плач, дозвољавају да се уздахне само једно „Ах!” као знак раздвајања љубавника, звук прекида љубавног доживљаја, докинутост језика љубави у сфери актуелизованих наративних феномена. То је закорачење у вербално невидљиво и скривено, односно у трансвербално, у виртуелно наративно, где се љубавна грозница обнавља на друкчији начин, а помирење слути: „Чекала да је ја први ословим, макар и најгрубље, а она ће већ одмах да ми попусти, моли ме, насмеје се, и тако да се измиримо" (Станковић 1970: 125). Јунаци Станковићевих приповедака свесни су какав утисак провоцира узајамно ословљавање, и баш зато приповедач одлучује да ћути, да остане снажан и издржи њен поглед. Ипак, управо љутња и увреде

које упућује Ленки откривају неуслишени вапај, молбу за љубављу, слабост заштитних оклопа. Како младић неколико пута понавља: „Нећу силом, нећу!” (Станковић 1970: 128), очитује се унутарња борба јунакаิ између сопствене 
рањивости али и спремности за другога, „тело је њихова страшна тамница, јер се у телу најпре и најсуровије распињу њихова два нагона: ја-за себе и ја-за другог” (Палавестра 1986: 422-423). Отвореност бића ка другоме „мами, али од велика, изненадна стида стрепи и трза се и од саме помисли на пољубац" (Станковић 1970: 128), те Ленка изговара само „не, не...” (Станковић 1970: 128), трудећи се да главом не одриче. Жмурећи пружа и лице, и уста, и око, и све, али не може начинити ниједан корак ка младићу. Ленка остаје притешњена између бесног и раскалашног „Ох” и болно умилног „Ах”, између напона жеље и стрепње да се та жеља може остварити.

Када је посреди приповетка „У ноћи”, занимљиво је осветлити морфологију имена, јер различити падежни облици одговарају новим идентификацијама јунака̂. У нарацији најучесталији облик имена јунакиње дат је у номинативу. Чини се да упућује на удату Цвету, згурену и уморну, на ону која је себе прежалила и оплакала. Међутим, како Стојан седам пута тихо изговара њено име у облику вокатива, у свет приче као да се уводи јунакињина двојница - Стојанова Цвета. Удвостручење лика последица је постојеће раселине у самој структури језика, чија се синтакса дестабилизује активирањем узвика̂ или вокатива. „Осим граматике, асинтаксичност вокатива у односу на појам реченичности истиче, претежно, и синтаксичка литература, у којој убједљиво преовладава став о синтаксичкој неукључености вокатива. Његову асинтаксичност истиче и А. Белић, сврставајући га у исту раван са узвицима" (Бабић 2011: 72). Ритмичност љубавног осећања знатно се појачава Стојановим распеваним дозивањем: „Цвет - о - о!” (Станковић 1970: 104), кликтањем милог имена, језичком егзалтацијом. Цветин одзив, обухватајући и негацију и име вољеног, „немој” и „, слатки Стојане...”, открива страх због могуће несреће, али и жељу да се заветује на љубав, будући да „чедност није стање тела, па чак ни својство личности; то је својство односа - једног према једној; и њихова јединственост једног за друго јесте запечаћена управо језиком личних имена" (Епштејн 2012: 290). Име, претворено у песму, показује како се Цвета одражава у Стојану, како одзвања у њему, и та звучна растегљивост имена јунакиње открива Стојанову преплављеност њоме, потребу да се Цветиним именом смисаоно определи свет, јер „властито име само почиње одређивати и преименовати све” (Епштејн 2012: 280).

Уколико обратимо пажњу на облике Стојановог имена, које Цвета изговара у заносу, може се приметити да прво ословљавање остаје без придева, да би се потом Стојановом имену прикључио придев 'слатки', јер „доста је, доста, слатки Стојане” (Станковић 1970: 104). Наслућује се извесна

\footnotetext{
${ }^{2}$ Речник српскохрватскога књижевног језика потврђује могућности различитог значења узвика 'ах': „ax узвик за изражавање: бола, жалости, радости, дивљења, одушевљења, чуђења, срџбе и сл." (Речник српскохрватскога књижевног језика; Къ. 1; А-E 1990: 114).
} 
(не)дисконтинуативност, једно од синтаксичких начела кохезије, којим се потврђује самосталност вокативне конструкције. Додавање атрибута имену драгог онемогућава уметање било какве треће речи (осим још којег атрибута), јер атрибут у наведеном примеру искључиво детерминише целину, односно управну именицу (в. Симић, Јовановић 2002б: 956-957). Употреба независне вокативне конструкције мотивисана је Цветином потребом за сагледавањем јединствености и целовитости Стојановог бића. Међутим, у моменту највишег љубавног усхићења наместо Стојановог имена појављује се заменица 'ти' као знак Цветиног апсолутног дивљења пред Стојаном, јер „запињати на 'ти' и 'такав' може само - глас чуђења, изласка из памети" (Епштејн 2012: 275). Када се љубавници растану, довољан је најмањи подстрек да у њима наново затрепти импулс љубавног усхићења, јер чувши Стојанову песму у даљини, Цвета једино може да се стресе: „У-у-ух” (Станковић 1970: 110)! Додирујући Цвету, звук Стојанових песама и речи претаче се у саму чулност и задобија тактилна својства. Овом приповетком Станковић је „наговестио особену поетику еротског доживљаја у којој се укрстила фолклорна традиција са модерном психолошком нарацијом” (Милосављевић Милић 2013: 73). Дочарана мирисима и соковима живота, атмосфера приповетке „У ноћи” употпуњена је сценом окопавања и наводњавања баште, што упућује на фолклорно порекло описа. Како је сусрет љубавника једино могућ у виртуелном свету лирске песме, естетски ефекат новине у Станковићевој прози - дуго скривани простор еротског - остварује се „у реторичкој равни симболизације, сублимације, па стога и релативизације еротске компоненте” (Милосављевић Милић 2013: 73).

Цвета више пута изговара узвик 'ох': на крају сусрета са Стојаном када се пита: „Ох, а шта тражи?” (Станковић 1970: 102), у тренутку готово бесвесног ужитка бранећи се: „Доста... видеће ко...ох!...” (Станковић 1970: 104), онда када се блажена и обамрла немоћно предаје Стојану: „Та доста... Ох, баш си ти?!...”' (Станковић 1970: 105). Пригушеним узвикивањем јунакиња поништава друге изговорене речи и њихова конкретна значења, ослобађа језик граматичких структура, активира непредвидиве и незавршиве семантичке могућности. Узвиком 'ох'’3 као да се чује историја љубави јунака̂, која у исто време одзвања нежношћу и страшћу, умилном молитвом и дрским призивањем. Узвик 'ох' може усмеравати ка ономе што је неизрециво и забрањено, ка „грчењу” љубави која не сме да се озвучи неком речју више осим срећним издахом.

Након сусрета са Стојаном, Цвета мисли на њих двоје, загрљене, далеко од света, али убрзано се трезни од тих мисли крстећи се и молећи Господу. Из тих разлога, узвици у Станковићевим приповеткама нису увек и љубавни

${ }^{3}$ У Речнику српскохрватскога књижевног језика узвик 'ох' има следећа значења: „ох (каткад удвојено) узвик за исказивање различитих расположења и осећања: радости, задовољства, жеље, туге, љутње, огорчења итд." (Речник српскохрватскога књижевног језика; Къ. 4; О-П 1990: 276). 
усклици, јер Цвета „дршћући од страха и кријући поглед од светлости” (Станковић 1970: 109), стрепи и вапи: „На месечини... Јаох!” (Станковић 1970: 108). Пригушено јауче увиђајући да би неко могао открити њену тајну, осећајући бол који не може друкчије исказати до узвиком 'јаох'. Када је посреди узвик 'ех', занимљиво је пратити могуће путање семантизације, будући да се овај узвик појављује у различитим контекстима. У првој комуникативној ситуацији, на Цветино подсећање да мора мислити на жену и децу, Стојан нехајно и мрзовољно, одбијајући руком и саму помисао на брак, изговара једно „ех”. Узвик 'ех' означава жалост због немогућности потврђивања сопствене егзистенције у узајамној љубави ${ }^{4}$. Трагични утицај патријархалног друштва на личну срећу човека, дискретно најављиван Цветином фигуром у тамној ноћи, сада узвиком 'ех' буди сећање на Цветину удају и Стојаново мучно привикавање на породични живот. Међутим, када Цвета пак покаже своју љутњу због Стојановог одласка, премда је то захтевала од њега, Стојаново радовање исказује се управо узвиком 'ех': „Ех, љутиш се ти!” (Станковић 1970: 102). С обзиром на то да Стојан оде „удивљено и пребацив мотику преко рамена” (Станковић 1970: 102), могуће је овом узвику доделити радикално друкчије значење у односу на првобитно. Речју 'ех' могу се исказати двосмислена значења, будући да усклик представља изненадни шапат радости али и малаксалу тугу, парадоксални положај љубавника који се истовремено подају и супротстављају заносу, јер озвучујући једно „ех” „Цвета се сагиње да сакрије радост и као крв румене образе" (Станковић 1970: 104).

Унутрашњи живот патријархалне жене најупечатљивије представљен је у приповеци „Покојникова жена”. Удовица Аница, још увек млада и лепа, остаје у тешко издрживој и застрашујућој вези са покојником. Премда се више и не сећа свога мужа, јер „памти га само по гробу” (Станковић 1970: 196), учестало на гробљу, где једино осећа олакшање, нариче: „Леле, Мито!” (Станковић 1970: 197) Иако се нарацијом значење узвика 'леле'5 усмерава у два правца, јер упитно је „да ли је тај плач био за њега ила за њу, саму себе” (Станковић 1970: 218), слутимо могућност још једног потенцијалног значења - плача за Итом. Комплексније семантичко рашчитавање ове приповетке наново бива омогућено употребом властитих именица. Чини се, фонолошка сличност покојниковог имена са именом Аничиног старог свата није случајна. С обзиром на то да се узвик појављује у спрези са вокативним обликом имена 'Мита', верујемо да се Аничин лелек може односити и на живог „покојника” - Иту,

\footnotetext{
${ }^{4}$ Према Речнику српскохрватскога књижевног језика узвик 'ех' може имати сасвим супротна значења: „ех узв. за појачавање и за изражавање различних расположења: драгости, вајкања, негодовања и сл." (Речник српскохрватскога књижсевног језика; Къ. 1; A-E 1990: 865).

${ }^{5}$ Узвик 'леле' у Речнику српскохрватскога кьижевног језика има утврђено значење: „Узв. за изражавање туге, бола, жалости: јао, куку" (Речник српскохрватскога књижевног језика; Књ. 3; $K-O$ 1990: 184).
} 
будући да након његове прошевине, лежећи као мртва, Аница очајно јеца: „Ито, Ито мој...”, те „као да је мртав, почне да кука, оплакује га” (Станковић 1970: 228). Неколико пута поновљено „Леле, Мито!” као да се претвара у свој ехо „Ито, Ито мој...”. У „Покојниковој жени” рајскост језика љубави чува се на парадоксалан начин. Аница се не преудаје за човека кога истински воли, јер покојник је, иако покојник, управо као покојник испречен између њих двоје. Покојник ју је увео у круг људи, у ред жена, те га она не може изневерити преудајом, недостојна је Ите, она је вечно покојникова, већ грљена и милована. Парадокс се састоји у томе што Аница пристаје на удају за Недељка, те се на известан начин браком штити један затворени и неповређени простор у свести Станковићевих јунака, један љубавни микрокосмос у коме су само њих двоје - Аница и Ита. „А да је он као сваки, муж, обичан, као тај Недељко, али ово је Ита. А друго је Ита, а друго је муж. А Ита је, Ита...” (Станковић 1970: 229) Посредством доживљеног говора примећује се покушај дефинисања вољеног бића, покушај стварања замисливих особености, међутим, одређујући Иту као Иту и никако друкчије, открива се немоћ језика да одреди јединственост љубљене особе. Име као да присваја све постојеће чиниоце света, самотумачењем и самопотврђивањем као да се приближава неком траженом смислу, који се невербално опредељује, виртуелним додирима и гестовима.

Аничин подређени положај у друштву и психологију условљену тим положајем, одредила су превасходно браћа и окружење. „А она, Аница, једино се по тој својој браћи и знала. Нико њу није звао њеним именом већ 'сестра на Рибинчики'.” (Станковић 1970: 203-204) Ако „сваки суфикс има свој психофизички набој” (Епштејн 2012: 278), онда суфикс -ица не доноси очекивано деминутивно-дечије значење. У Станковићевом језику љубави овај облик имена јунакиње показује заправо докинутост женске фигуре, сведеност и осакаћеност Аничине женскости. Име јунакиње не само да посведочава начетост и недовршеност женског идентитета већ подразумева и неостваривост Аничиног бића као јединственог бића. Напрасита браћа, чувене убице и кријумчари, наметнула су свим члановима колектива такав однос према јунакињи, те њено име, услед регистроване прикраћености женске природе, неће моћи да изговори и Ита. „Мајку и њу, Аницу, они нису ни разликовали. Сматрали су их као једнаке, називајући их 'жене'." (Станковић 1970: 205) У тој једнакости са мајком и варошким женама, Аница ипак покушава да се одржи, да се покаже Ити „само као сестра, као снајка, а не друго” (Станковић 1970: 213). Љубавни дијалог догодио се у тами, током Аничине прве брачне ноћи, у карактеристичној атмосфери Станковићеве прозе, која оставља вољено у безјезичном, недореченом, неименованом, у ноћи која допушта само сурогате љубави, једно једва изговорено „снајка” и промуцано „брате”, док се трудила да „У ту реч метне, даิ што више сестринске, само сестринске љубави” (Станковић 1970: 212). Рајскост језика претрајава у лирској песми, 
као у приповеткама „У ноћи” и „У виноградима”, трансвербално сели се у мелодију, која функционише као специфични облик постојања овог феномена у приповедним текстовима. Јунаци Станковићевог фикционалног света проналазе неслућене могућности инкорпорирања љубавних фрагмената у актуелни говор, те Итино питање: „Хоћеш да ти певам?” (Станковић 1970: 212) постаје својеврсна љубавна лозинка тајног језика и скривени договор најмање језичке заједнице - заједнице љубавникаิ. Допуштајући Аничином лику најинтензивније самоубилачке помисли али и најслободнија сањарења у самоћи, приповедач ефектно потцртава двогубост својих јунакиња и двојакост света приче. Двосмерност Станковићеве поетике приповедања уочио је и Радован Вучковић:

„На једној страни је артистички успело изведена композиција, егзактан, као у филму, начин повезивања призора и сцена, драмски карактер структуре, натуралистички жива и брутална репродукција стварног, ружног и патолошког, а на другој, поетична љубав, симболичка интеграција и преобразба реалности, психолошки оштар продор у личност и отварање подсвесних регија бића, општа спиритуализација грубе материјалности живота" (Вучковић 2014: 281).

\section{„ВЛАСТИТОСТ” ЖЕЉЕ}

Језик бива спиритуализован укидањем схематизованих љубавних изјава („волим те”, ,љубим те”, „желим те” и сл.) и усредсређеношћу на само један објекат љубави. Властите именице поништавају општост и апстрактност љубави, јер сви могуће корелације љубави са бескрајним низом објеката, од завичаја до идеала, бивају учвршћене у једном имену или пак једном корену речи. Јунаци Станковићевих приповедака не уживају у заносу изазваном сталном мишљу о љубави, њихова љубав прелази у друкчију структуру - у „властиту” жељу. Када жеља губи своју „заједничкост”, „она се и суштински мења, постаје врелија, дрскија, незаустављива: њен излаз се сужава - и жеља пенуша, шикља, прелива се преко ивице, већ готово луда у својој пробирљивости" (Епштејн 2012: 289). То преливање жеље на језичком плану очитује се заумима, морфолошким необичностима, разгранавањем узвика, покушајима прекорачења свих граматичких образаца. Језик љубави почива на жељи да се „властитост” речи прослави. С друге стране, преливање „властите” жеље оприсутњује се симболичким описима јунакиња које се журно крећу улицом, стидећи се и повијајући главе, скривајући једрост својих тела. Иако измучене и уморне, у вечној борби између разума и чула, уплетене у немилосрдну игру са околином, и Ленка, и Цвета, и Аница, не губе лепоту, занос и страст.

\footnotetext{
„Иду оне лако, плашљиво. Држе се рука за руку и косо окрећу к зиду, да им 'мушкарци' не виде набрекле груди.” (Станковић 1970: 121)

„Брада овална, а тамни јој и румени образи одскочили од стегнуте шамије, коса јој се извукла и пала по челу чак до мрких јој и крупних, влажних очију.” (Станковић 1970: 124)
} 
„Само је почела брже да окреће чекрк, а при том да јој се пуна, млада снага увија, крши; да јој груди више одскачу, а обле јој мишице на грудима да се показују, затежу минтан.” (Станковић 1970: 124)

„Уплакано јој лице зажарило се, букнуло, а и цела јој снага као набрекла. Хаљине joj тесне. А осећа како јој се прса шире, отимају се из тесног количета, излазе напоље, виде се... Зато од стида сагиње главу, намиче још више шамију, да јој се једва виде очи и уста, која још не могу да се умире од плача, већ јој дршћу.” (Станковић 1970: 198-199)

Преливање жеље преко ивице тела, упркос еротској засићености ових описа, активира сублимирана значења, која уводе језик у домен чедности. Ако је посреди „властитост” жеље, онда неомеђено кретање жеље афирмише Станковићев језик као језик појединачности и посебности, рајски језик пре првог греха и пре зидања Вавилонске куле, о којем се једино зна „да су у њему постојале само именице, и да су све оне биле властите” (Епштејн 2012: 290) [подвукао М. Е.]. У досадашњим истраживањима и спроведеним реконструкцијама савршеног прајезика, именице су замишљене као самосталне суштине, које садрже у себи сва својства предикативности или атрибутивности ${ }^{6}$. Такве именице, заједно са узвицима, преображавају друге речи, те рајски језик „захваљујући чуду своје 'именовативности', поново настаје унутар сваког 'поствавилонског језика' - у његовој посебној врсти, у љубавном говору" (Епштејн 2012: 292). Дакле, рајскост Станковићевог језика није посебна супстанца језика, већ начин поступања са постојећим језичким чиниоцима, што и Миланка Бабић увиђа приликом употребе разноврсних узвика:

\begin{abstract}
„На основу анализе особина узвика као врста ријечи, намеће се закључак да означеним код узвика није обухваћен појам одређен конвенционалним релацијама језичког знака, него прије спонтаним сензорно-когнитивним процесима. (...) Будући да не остварује ни деривацијске везе са другим језичким јединицама примарног значењског гнијезда, узвик се тек секундарним језичким описом доводи у везу са њима. Природа ситуације у којој се узвик употребљава дозвољава да уобличимо узвик у току говорног чина избором из репертоара тој ситуацији одговарајућих гласовних комбинација. Зато је - у односу на пунозначне лексеме - узвик мање конвенционализован или флексибилно конвенционализован знак, најчешће фоносимболичка представа одређеног стања или ситуације" (Бабић 2010: 215-216).
\end{abstract}

\title{
ЗАКЉУЧАК
}

Семантичке разлике међу узвицима 'ax', 'ех' и 'ох' предочавају степене трагичности Станковићевих јунакиња7. Ленкино „ах” означава раздвајање у

\footnotetext{
${ }^{6} \mathrm{O}$ реконструкцији рајског прајезика, в. две књиге Умберта Ека: Search for a Perfect Language, Oxford, Blackwell, 1995; Serendipities: Language and Lunacy, San Diego, New York, London, Harcourt Brace \& Co, 1999.

${ }^{7}$ Миланка Бабић сврстава речи 'ах', 'ех' и 'ох' у експресивне узвике издвајајући семантичку варијабилност као једну од примарних карактеристика ових језичких јединица: „Без изразитих морфолошких обиљежја, дакле, без поузданог лексичког значења, без могућности синтаксичког повезивања са другим ријечима, узвици се одређују и класификују углавном на основу
} 
садашњости, страх у актуелном наративу када јунакиња не сме да се препусти искреним и снажним емоцијама. Стојаново и Цветино „ех” превасходно раскрива жалост и сету за прошлим данима, стога се овај узвик може семантички осенчити вишим ступњем трагичности, будући да временска дистанца удвостручава тугу због губитка љубави. Узвиком 'ех' као да се истовремено активирају две временске равни, унутар којих се једном доживљено отцепљење изнова актуелизује у садашњости и бескрајно понавља не завршавајући се и остајући увек између једва упућених речи и скривених мисли о потенцијалном заједничком животу. Узвик 'ох' не само да Цветиним уздахом очитује еротски врхунац, већ Аничиним очајним шапатом постаје знак еротског контрапункта, клетва над празнином и „несташицом” љубави: „Ох, пусто остало!” (Станковић 1970: 104) Узвик 'ох' оглашава лелек над сопственом судбином и коначно сазнање јунакиње о безнађу. За емотивне узивике карактеристична је управо оваква полисемичност повишеног степена, када једна реч, пратећи промену интонације, означава супротна психичка стања (в. Даковић 2000: 5). Сугласник $x$ као да упућује на запреке у животима Станковићевих јунакиња. С друге стране, будући да веларне консонанте одликују снажна еспресивност и импресивност (в. Прћић 1999: 13), сва три узвика сугласником $x$ не само да проширују семантички распон одабраних приповедака, већ потврђују и сопствену фоностилистичку вредност.

Истичући фонолошки аспект језика и различите интонативне могућности, Станковићев језик љубави показује да распевани облици вокатива и узвици „нису механичке последице психичких стања већ језичко средство за њихово изражавање” (Дикро, Тодоров 1987: 299). Експресивна функција језика опстаје, дакле, као независни и особени начин преношења значења. Писац ваљано разлучује емотивну од референцијалне функције језика, знајући да није исто изразити психичко стање и репрезентовати га „као предмет неког исказа” (Дикро, Тодоров 1987: 299). Емотивне јединице не укидају информациони капацитет језика, нису само изрази одређене воље, емоције или става, допуњују сазнајни аспект језика, јер „емотивна функција, најиспољенија у узвицима, у извесној мери даје боју свим нашим исказима, и то на њиховом гласовном, граматичком и лексичком нивоу” (Јакобсон 1966: 291).

семантичко-прагматичких критеријума - с обзиром на то у којој ситуацији се употербљавају и с каквим комуникативним учинком. У примарној класификацији ове врсте ријечи оправдано је издвојити три групе речи: 1) експресивне, 2) контактне, 3) имитативне узвике. Првој групи припадају узвици којима се у први план ставља говорно лице и његов однос према говорној ситуацији или неком елементу исказаног садржаја. Они служе за изражавање духовних стања или расположења и експресивних ставова. Називамо их експресивним узвицима. Њима се исказују индивидуална стања говорника изазвана различитим стимулансима: ax, ox, yx, ex, jy, уф и сл." (Бабић 2010: 207-208). 
На фонолошком плану, „озвучени” облици вокатива и узвици имају важну улогу у конструкцији субјекта. На морфолошком нивоу, властита имена у вокативу откривају учесталу усредсређеност језика на пошиљаоца, на другога, на саговорника. Језик љубави не само да се ствара захваљујући експресивној већ и конативној језичкој функцији. У знатном броју примера узвици и вокатив присвајају иницијалну или финалну синтаксичку позицију, те слутимо да ове врсте речи опредељују управо гранични положај, у коме се налазе субјекти Станковићеве нарације. Упућују на позицију између патријархалног и личног, оствареног и неоствареног, жељеног и живљеног, виртуелног и актуелног. Љубавни језик Борисава Станковића представља похвалу српском језику и осећању српске књижевности за љубавно именовање. Варијанте умилних обраћања и „озвучавања” најделикатнијих лингвистичких могућности доприносе потврди значаја и проширивању значења рајског језика личних имена, па тако и увећању пажње за односе међу људима и за тајновите димензије људског бића.

\section{ЛИТЕРАТУРА}

Бабић 2010: М. Бабић, Огледи из прагматичке синтаксе, Источно Сарајево: Филозофски факултет.

Бабић 2011: М. Бабић, Морфолошко-синтаксичке специфичности вокатива, Српски језик: студије српске и словенске, 16/16, Београд, 69-82.

Бабић 2015: М. Бабић, Синтаксички и стилистички огледи, Београд: Јасен.

Белић 1941: А. Белић, О језичкој природи и језичком развитку. Лингвистичка испитивања, Београд, према: Н. Петковић, Два српска романа: студије о Нечистој крви $u$ Сеобама, Београд: Народна књига, 69.

Белић 1959: А. Белић, О језичкој природи и језичком развитку. Лингвистичка испитивања, књ. II, Београд, према: Н. Петковић, Два српска романа: студије о Нечистој крви $и$ Сеобама, Београд: Народна књига, 70.

Бошковић 2017: Д. Бошковић, Нулти степен реализма, Крагујевац: Филолошко-уметнички факултет.

Вучковић 2014: Р. Вучковић, Модерна српска проза, Београд: Службени гласник.

Глигорић 1952: В. Глигорић, Предговор, у: Б. Станковић, Одабране странице, Београд: Ново поколење. 
Даковић 2000: С. Даковић, Још о узвицима, Језик данас: гласило Матице српске за културу усмене и писане речи, 4/12, Нови Сад, 3-9.

Деретић 2002: J. Деретић, Историја српске књижевности, Београд: Просвета.

Дикро, Тодоров 1987: O. Dikro, C. Todorov, Enciklopedijski rečniknauka o jeziku II, Beograd: Prosveta.

Еко 1995: U. Eco, Search for a Perfect Language, Oxford: Blackwell.

Еко 1999: U. Eco, Serendipities: Language and Lunacy, San Diego, New York, London: Harcourt Brace \& Co.

Епштејн 2012: М. Епштејн, Философија љубави: љубав у пет димензија, Сремски Карловци: Нови Сад: Издавачка књижарница Зорана Стојановића.

Јакобсон 1966: R. Jakobson, Lingvistika i poetika, Beograd: Nolit.

Јерков 1992: А. Јерков, Иманентна поетика Андрићевих романа, Свеске $3 a$ дужбине Иве Андрића, год. 11, св. 8, 200-236.

Милосављевић Милић 2013: С. Милосављевић Милић, Отпори и прекорачења: поетика приповедања Боре Станковића, Ниш: Филозофски факултет Универзитета.

Мукаржовски 1987: J. Mukaržovski, Struktura, funkcija, znak, vrednost: ogledi iz estetike i poetike, Beograd: Nolit.

Палавестра 1986: П. Палавестра, Историја модерне српске књижевности: златно доба 1892-1918, Београд: Српска књижевна задруга.

Петковић 1988: Н. Петковић, Два српска романа: студије о Нечистој крви и Сеобама, Београд: Народна књига.

Прћић 1999: Љ. Прћић, О узвицима у српском језику, Језик данас: гласило Матице српске за културу усмене и писане речи, 3/10, Нови Сад, 12-14.

Речник српскохрватскога књижевног језика; Књ. 1; А-Е 1990: Речник српскохрватскога къижевног језика; Къ. 1; A-E, (ур.) Михаило Стевановић и др., Нови Сад: Матица српска; Загреб: Матица хрватска.

Речник српскохрватскога књижевног језика; Къ. 3; К-О 1990: Речник српскохрватскога књижевног језика; Къ. 3; K-O, (ур.) Михаило Стевановић и др., Нови Сад: Матица српска; Загреб: Матица хрватска. 
Речник српскохрватскога књижевног језика; Кю. 4; О-П 1990: Речник српскохрватскога књижевног језика; Кю. 4; О-П, (ур.) Михаило Стевановић и др., Нови Сад: Матица српска; Загреб: Матица хрватска.

Симић 2001: Р. Симић, Опита стилистика, Београд: Друштво за неговање и проучавање српског језика; Никшић: Јасен.

Симић, Јовановић 2002а: Р. Симић, Ј. Јовановић, Српска синтакса: I. - II., Београд: Филолошки факултет: Научно друштво за неговање и проучавање српског језика; Никшић: Филозофски факултет; Подгорица: Црногорски универзитет; Београд [тј.] Никшић: Јасен.

Симић, Јовановић 2002б: Р. Симић, Ј. Јовановић, Српска синтакса: III. - IV., Београд: Филолошки факултет: Научно друштво за неговање и проучавање српског језика; Никшић: Филозофски факултет; Подгорица: Црногорски универзитет; Београд [тј.] Никшић: Јасен.

Солар 1985: M. Solar, Filozofija književnosti, Zagreb: Sveučilišna naklada Liber.

Чаркић 2009: А. Чаркић, Граматичари о узвицима, Стил: међународни часопис, бр. 8, Београд, 279-290.

Чаркић 2010: А. Чаркић, Лингвисти о узвицима, Стил: међународни часопис, бр. 9, Београд, 399-407.

\section{Извори}

Станковић 1970: Б. Станковић, Стари дани; Божји људи, Сабрана дела Борисава Станковића, књ. I, Београд: Просвета.

\section{THE LANGUAGE OF LOVE IN BORA STANKOVIĆ'S STORIES: PROPER NOUNS AND EXCLAMATIONS}

\section{Summary}

Applying the knowledge from anthroponimy (science of people's names), general linguistics and philosophical hermeneutics, we explore the multiple meanings of proper names and exclamations in three Stanković's stories: „In Vineyards”, „In the Night” and „The Deceased's Wife”. We pay attention to semantic differences between the exclamations 'ah', 'eh' and 'oh', introducing not only the degrees of tragedy, but also particular a grammar of love, the two being a verbal and transverbal specialty of Stanković's language. Based on our research, we conclude that Stanković's love poetics does not only arise through the use of simple linguistic means focused on clear and concrete references, but also opens pos- 
sibilities for far reaching semantic nuances of the Serbian language, hypothetical signification of lexical and grammatical structures, and individual and unique values. The language of love is primarily created by the connotative and expressive linguistic functions.

Key words: Bora Stanković, proper nouns, exclamations, preverbal, transverbial

Anka Ž. Simić, Ana S. Živković 